Article

\title{
Effects of Jasmonic Acid in ER Stress and Unfolded Protein Response in Tomato Plants
}

\author{
Zalán Czékus ${ }^{1,2}$, Orsolya Csíkos ${ }^{1}$, Attila Ördög ${ }^{1}{ }^{(0}$, Irma Tari ${ }^{1}$ and Péter Poór ${ }^{1, *(1)}$ \\ 1 Department of Plant Biology, University of Szeged, Közép fasor 52, H-6726 Szeged, Hungary; \\ czekus.z@bio.u-szeged.hu (Z.C.); borsika94@hotmail.com (O.C.); aordog@bio.u-szeged.hu (A.Ö.); \\ tari@bio.u-szeged.hu (I.T.) \\ 2 Doctoral School of Biology, University of Szeged, Közép fasor 52, H-6726 Szeged, Hungary \\ * Correspondence: poorpeti@bio.u-szeged.hu
}

Received: 22 May 2020; Accepted: 8 July 2020; Published: 10 July 2020

\begin{abstract}
Endoplasmic reticulum (ER) stress elicits a protective mechanism called unfolded protein response (UPR) to maintain cellular homeostasis, which can be regulated by defence hormones. In this study, the physiological role of jasmonic acid (JA) in ER stress and UPR signalling has been investigated in intact leaves of tomato plants. Exogenous JA treatments not only induced the transcript accumulation of UPR marker gene SlBiP but also elevated transcript levels of SIIRE1 and SIbZIP60. By the application of JA signalling mutant jai1 plants, the role of JA in ER stress sensing and signalling was further investigated. Treatment with tunicamycin (Tm), the inhibitor of $\mathrm{N}$-glycosylation of secreted glycoproteins, increased the transcript levels of SIBIP. Interestingly, SIIRE1a and SIIRE1b were significantly lower in jai1. In contrast, the transcript accumulation of Bax Inhibitor-1 (SIBI1) and SlbZIP60 was higher in jai1. To evaluate how a chemical chaperone modulates Tm-induced ER stress, plants were treated with sodium 4-phenylbutyrate, which also decreased the Tm-induced increase in SIBiP, SIIRE1a, and SIBI1 transcripts. In addition, it was found that changes in hydrogen peroxide content, proteasomal activity, and lipid peroxidation induced by Tm is regulated by JA, while nitric oxide was not involved in ER stress and UPR signalling in leaves of tomato.
\end{abstract}

Keywords: ER stress; jasmonic acid; nitric oxide; protein carbonylation; reactive oxygen species; unfolded protein response

\section{Introduction}

A wide range of biotic and abiotic stress factors can disrupt the protein-folding capacity and the transport balance of the endoplasmic reticulum (ER), which results in the accumulation of misfolded or unfolded proteins in the lumen of ER and thus induces ER stress in plants [1-4]. The disturbances in ER homeostasis trigger an evolutionarily conserved response, termed the unfolded protein response (UPR). UPR is a protective process to maintain the cellular homeostasis by regulating the expression of variety of genes (e.g., chaperones) and by reducing protein loading to ER and enhancing ER-associated protein degradation (ERAD) [4-7]. Programmed cell death (PCD) and autophagy are also in tight connection with ERAD response, especially under chronic stress [8-11]. These ER-mediated stress responses in plants can be regulated by phytohormones but the activation of the UPR pathway by defence-related hormones remains mostly unclear [12].

At least two UPR pathways have been identified in plants. One of them, the inositol-requiring enzyme 1 (IRE1)-mediated unconventional splicing of basic leucine zipper (bZIP) 60 is the most characterised pathway in eukaryotes [13-15]. Briefly, the accumulation of unfolded proteins leads to BiP (luminal binding protein) dissociation from IRE1, which becomes firstly dimerized, then finally oligomerized in the ER membrane. Following that, the activated RNAse function of IRE1 results 
in the splicing of bZIP60 mRNA and the bulk degradation of selected mRNAs through regulated IRE1-dependent decay (RIDD) in yeast, animals, and plants. The spliced bZIP60 mRNA is translated to an active transcription factor (TF) and by up-regulating the UPR-related genes helps the protein folding and degradation [13,16-19]. The activation of ER membrane-anchored TF bZIP28 and the plant B-cell lymphoma2 (Bcl-2)-associated athanogene 7 (BAG7) protein is another mode to control ER stress in plants. Based on the investigation in Arabidopsis, both proteins are anchored to the ER membrane by interactions with $\mathrm{BiP}$, which is an ER chaperone under control condition. bZIP28 is also activated through the stress-induced accumulation of unfolded proteins in the ER lumen. BiP dissociates from bZIP28 and the released bZIP28 translocates from ER to the Golgi, where it is proteolytically cleaved by Site-2 protease (S2P) under ER stress. The cleaved form of bZIP28 moves into the nucleus and binds to the ER stress element (ERSE) cis-regulatory motifs to activate the UPR gene expression [19-24]. BAG7 is also released from the ER membrane by an unknown protease; then, it is sumoylated and enters the nucleus, where it interacts with WRKY29 transcription factor and regulates the expression of various chaperone proteins to mitigate ER stress in Arabidopsis [25]. Another TF, the plant-specific NAM, ATAF, and CUC (NACs) TFs (e.g., NAC062 and NAC089) have been recently described as important regulators of ER stress responses that also undergo proteolytic cleavage and translocation to the nucleus to promote the transcription of UPR or PCD genes in Arabidopsis [2,4]. Unfortunately, most of the components of ER stress and UPR are identified in the Arabidopsis model plant, and only a few studies have examined these processes in crops, where the knowledge of the homologue signalling components is very limited [12]. The investigation of ER stress and UPR in cultivated plants could have great importance under diverse biotic and abiotic stress conditions from the agricultural aspect.

Since UPR plays a fundamental role in plant immunity and stress responses, the potential regulatory role of defence hormones in this process is relevant under the changing environment [12]. It has been demonstrated that various environmental stresses such as salinity or high temperature can cause ER stress and induce UPR in plants [26-28]. In conjugation with these, it has been demonstrated that several phytohormones are involved in the induction of ER stress and regulation of UPR, such as auxin or salicylic acid (SA) [29-31]. Although the role of SA in ER stress signalling and UPR has been almost fully characterised recently, the underlying mechanisms, interactions, and the potential molecular and physiological role of other defence-related phytohormones such as jasmonic acid (JA) has not yet been completely described $[4,12,32,33]$. Besides SA, JA also plays a crucial role during the plant-pathogen interactions and in resistance processes upon abiotic stressors [34-39]. JA promotes the production of antifungal proteins, such as defensins and protease inhibitors within hours after the infection or wounding, as well as increases the activity of various defence enzymes [37,40]. The rapid and optimal coordination of protein secretory machinery is required to ensure folding, modification, and transport of stress-related proteins, but the potential role of JA in these processes and UPR is not known in full detail. Interaction between JA and UPR marker BiP chaperone was confirmed recently in BiP-overexpressing transgenic soybean plants, where JA content was significantly lower compared to wild-type (WT) plants under control condition [41]. Firstly, Moreno et al. [42] tested the effects of methyl jasmonate (MeJA) in Arabidopsis. Their results showed that $0.03 \mathrm{mM}$ MeJA failed to activate bZIP60 mRNA processing within $5 \mathrm{~h}$. More recently, Xu et al. [33] demonstrated that MeJA in the concentration of $1 \mathrm{mM}$ can transiently induce UPR marker genes within $3 \mathrm{~h}$. The expression of BiP, protein disulfide isomerase (PDI), calnexin (CNX), and calreticulin (CRT) was at its maximum after $3 \mathrm{~h}$ but the transcript levels of bZIP60 were significantly higher after $12 \mathrm{~h}$ in Arabidopsis exposed to $1 \mathrm{mM}$ MeJA [33]. These gene expression data suggest a rapid and concentration-dependent effect of MeJA, but the biochemical and physiological changes have neither been investigated in Arabidopsis nor in crops. Among others, the production of reactive oxygen species (ROS), lipid and protein oxidation, and the regulated and non-regulated degradation of damaged proteins are key components of these processes [43], but the role and effects of JA are less known.

JA receptor and signalling mutants make it possible to analyse not only the molecular steps of signalling but also the physiological functions of JA under stress conditions. The jasmonic 
acid-insensitive1 (jai1), which is defective in JA signalling, is one of the best-characterised tomato mutants. It was described earlier that these sterile mutants cannot express JA-responsive genes and cannot accumulate JA-regulated proteinase inhibitors. Moreover, these mutant plants are severely resistant to two-spotted spider mites [44]. To test the potential role of JA in UPR, exogenous treatment with tunicamycin (Tm, the inhibitor of N-glycosylation of secreted glycoproteins) can provide an opportunity to provoke ER stress in leaf tissues under laboratory conditions [14].

In this work, the rapid effect of JA was investigated in ER stress sensing and signalling in intact leaves of tomato plants. Changes in the transcript accumulation of UPR marker BiP gene, as well as the transcript levels of ER stress sensor SIIRE1 and UPR transcription factor SlbZIP60 were also detected upon exogenous JA treatments. The potential physiological role of JA in ER stress sensing and UPR was investigated the first time in jai1 plants which are defective in JA signalling. Our experiments were focused on the JA-mediated ROS and nitric oxide (NO) production, as well as lipid and protein oxidation under UPR.

\section{Materials and Methods}

\subsection{Plant Material and Growth Conditions}

Seeds of wild-type (WT) and jasmonic acid-insensitive1 (jai1) tomato plants (Solanum lycopersicum L. cv. Castlemart) were germinated for 3 days at $26^{\circ} \mathrm{C}$ under darkness (Seeds were kindly provided by Dr. Bettina Hause (Leibniz Institute of Plant Biochemistry, Halle, Germany) and Dr. Gregg Howe (Michigan State University, East Lansing, MI, USA)). Homozygous jai-1/jai-1 seedlings were pre-selected by treatment with $1 \mathrm{mM}$ methyl jasmonate (MeJA) during the germination [45]. MeJA-insensitive seedlings (jai-1/jai-1) did not suffer any growth inhibition or showed a violet colour compared to the sensitive ones exposed to MeJA. The selected seedlings were transferred to perlite for 14 days; then, they were placed in hydroponic culture and plants were grown under a controlled environment $\left(200 \mu \mathrm{mol} \mathrm{m}{ }^{-2} \mathrm{~s}^{-1}\right.$ photon flux density, F36W/GRO lamps (OSRAM SYLVANIA, Danvers, MA, USA) with 12/12-h light/dark period, day/night temperatures of $24 / 22{ }^{\circ} \mathrm{C}$ and a relative humidity of 55-60\%) [46]. Before the experiments, the insensitive plants were subjected to a PCR analysis to select the homozygous ones [44].

\subsection{Chemical Treatments}

Tomatoes at the five-leaf stage were treated by adding $1 \mu \mathrm{M}$ or $10 \mu \mathrm{M} \mathrm{JA}$ to the nutrient solution for $6 \mathrm{~h}$ to test the effects of JA on WT plants. Both genotypes were subjected to the treatment of the ER stress-inducer Tm $\left(0.5 \mu \mathrm{g} \mathrm{mL}^{-1}\right)$ via the nutrient solution. To evaluate the effects of chemical chaperone on Tm-induced ER stress, plants were incubated in the nutrient solution with $1 \mathrm{mM}$ sodium 4-phenylbutyrate (PBA) chemical chaperone in the presence of $0.5 \mu \mathrm{g} \mathrm{mL}^{-1} \mathrm{Tm}$ for $6 \mathrm{~h}$ [47]. All chemicals were purchased from Sigma-Aldrich (Sigma-Aldrich, St. Louis, MO, USA). All experiments were started at 9:00 ( $3 \mathrm{~h}$ after light on) and were repeated three times. The samples were prepared from fully expanded leaves in three replicates, $6 \mathrm{~h}$ after the treatments.

\subsection{Analyses of Transcript Accumuation by Quantitative Real-Time PCR}

Total RNA was isolated from leaves using the TRI reagent method [48]. Genomic DNA digestions were performed by DNase I (Fermentas UAB, Vilnius, Lithuania) and the first-strand CDNA was synthesized using MMLV reverse transcriptase (Fermentas UAB, Vilnius, Lithuania). Quantitative real-time-PCR (qRT-PCR; qTOWER Real-Time qPCR System, Analytik Jena, Jena, Germany) was used to detect the transcript accumulation of the selected tomato genes (Table 1) mined from the National Center for Biotechnology Information Search database [49]. 
Table 1. Primer pairs used for qRT-PCR.

\begin{tabular}{ccc}
\hline Gene (Locus) & Reverse/Forward & Sequence $\mathbf{( 5}^{\prime}$-3') \\
\hline \multirow{2}{*}{ SlBiP (L08830) } & Reverse & $5^{\prime}$-TCAGAAAGACAATGGGACCTG-3' \\
\cline { 2 - 3 } SIDEF1 (NM_001346524) & Forward & $5^{\prime}$-GCTTCCACCAACAAGAACAAT-3' \\
\cline { 2 - 3 } & Reverse & $5^{\prime}$-GGCACAATCCATTCGTTTCT-3' \\
\hline \multirow{2}{*}{ SIIRE1a $($ XM_004232529) } & Forward & $5^{\prime}$-TTGGTCCCATTTCAGTAGCC-3' \\
\cline { 2 - 3 } & Reverse & $5^{\prime}$-CGCTTTACATCACCAGGACA-3' \\
\hline \multirow{2}{*}{ SIIRE1b (XM_004238397) } & Forward & $5^{\prime}$-CAGCAGCCCCTATTTCAGC-3' \\
\cline { 2 - 3 } & Reverse & $5^{\prime}$-CCAGTCCTCTATTGCCTCTCA-3' \\
\hline \multirow{2}{*}{ SlbZIP60 (XM_004238421.3) } & Forward & $5^{\prime}$-CCTGACCTAAATGCCCAGAT-3' \\
\cline { 2 - 3 } & Reverse & $5^{\prime}$-TTGCTGCCGAATCTCTTTCT-3' \\
\hline \multirow{2}{*}{ SIBI1 (NM_001247521) } & Forward & $5^{\prime}$-CGACTGGGAAACCTTGTGTT-3' \\
\cline { 2 - 3 } & Reverse & $5^{\prime}$-CTCAAAAACTTCCGCCAGAT-3' \\
\hline
\end{tabular}

The PCR reaction mixture contained $10 \mathrm{ng}$ cDNA template, 400-400 nM forward and reverse primers, $5 \mu \mathrm{L}$ of Maxima SYBR Green qPCR Master Mix (2X) (Thermo Scientific, Waltham, MA, USA) and nuclease-free water in $10 \mu \mathrm{L}$ volume (denaturation at $95^{\circ} \mathrm{C}$ for $7 \mathrm{~min}$, followed by 40 cycles of denaturation at $95^{\circ} \mathrm{C}$ for $15 \mathrm{~s}$ and annealing extension at $60^{\circ} \mathrm{C}$ for $60 \mathrm{~s}$ ). qTOWER Software 2.2 (Analytik Jena, Jena, Germany) was used to analyse the data [50]. Tomato $18 \mathrm{~S}$ rRNA and elongation factor- $1 \alpha$ subunit were applied as reference genes, and the data were calculated by the $2^{(-\Delta \Delta C t)}$ formula [51].

\subsection{Determination of Hydrogen Peroxide $\left(\mathrm{H}_{2} \mathrm{O}_{2}\right)$ Content}

First, $200 \mathrm{mg}$ of leaf tissue was homogenised with $1 \mathrm{~mL}$ of ice-cold, $0.1 \%$ trichloroacetic acid (TCA). Then, the samples were centrifuged $\left(11,500 \times g\right.$ for $10 \mathrm{~min}$ at $\left.4{ }^{\circ} \mathrm{C}\right)$. Then, $0.25 \mathrm{~mL}$ of the supernatant was added to the reaction mixture, which contained $0.25 \mathrm{~mL}$ of $50 \mathrm{mM}$ phosphate buffer ( $\mathrm{pH} 7.0)$ and $0.5 \mathrm{~mL}$ of $1 \mathrm{M}$ potassium iodide (KI). After $10 \mathrm{~min}$, the absorbance of the samples was measured at 390 nm with spectrophotometer [52]. The amount of $\mathrm{H}_{2} \mathrm{O}_{2}$ was calculated using a standard curve of $\mathrm{H}_{2} \mathrm{O}_{2}$ solution (Sigma-Aldrich, St. Louis MO, USA).

\subsection{Detection of Nitric Oxide (NO) Production}

NO production in tomato leaves was visualized using 4-amino-5-methylamino$2^{\prime}, 7^{\prime}$-difluorofluorescein diacetate (DAF-FM DA) (Sigma-Aldrich, St. Louis, MO, USA). Leaf discs were infiltrated with $10 \mu \mathrm{M}$ DAF-FM DA under vacuum for $30 \mathrm{~min}$ (the dye was solved in $10 \mathrm{mM}$ Tris- $\mathrm{HCl}, \mathrm{pH}$ 7.4) in the dark at room temperature. Following the infiltration, the samples were rinsed twice with $10 \mathrm{mM}$ Tris- $\mathrm{HCl}$ (pH 7.4). Fluorescence intensity of stained leaf samples was detected with a Zeiss Axiowert 200M-type fluorescence microscope (Carl Zeiss Inc., Jena, Germany) equipped with a high-resolution digital camera (Axiocam HR, Carl Zeiss Inc., Jena, Germany). Data were analysed by AXIOVISION REL. 4.8 software (Carl Zeiss Inc., Munich, Germany) [53].

\subsection{PROTEIN Extraction}

Soluble proteins were extracted from $250 \mathrm{mg}$ leaf tissues with $1 \mathrm{~mL}$ of $50 \mathrm{mM}$ sodium-acetate buffer ( $\mathrm{pH}$ 6.1) at $4{ }^{\circ} \mathrm{C}$. The extract was centrifuged $\left(11,500 \times g, 4{ }^{\circ} \mathrm{C}, 10 \mathrm{~min}\right)$; then, the total protein content of supernatants was determined by the method of Bradford et al. [54]. 


\subsection{Determination of Protein Carbonylation}

First, $750 \mu \mathrm{L}$ of $10 \mathrm{mM}$ 2,4-dinitrophenylhydrazine (DNPH) in $2 \mathrm{M} \mathrm{HCl}$ was added to $60 \mu \mathrm{g}$ protein extract and incubated in the dark for $1 \mathrm{~h}$ being vigorously mixed every $10 \mathrm{~min}$. The labelling was stopped by adding $0.5 \mathrm{~mL}$ of $20 \% \mathrm{TCA}$, and the samples were left on ice for $10 \mathrm{~min}$. After centrifugation $\left(11,500 \times g, 4^{\circ} \mathrm{C}, 10 \mathrm{~min}\right)$, the pellet was washed three times with $1 \mathrm{~mL}$ of ethanol:ethyl acetate $(1 / 1, v / v)$. After each washing step, the samples were centrifuged $\left(10,000 \times g, 4{ }^{\circ} \mathrm{C}, 10 \mathrm{~min}\right)$. The final pellet was dissolved in $1 \mathrm{~mL}$ of $6 \mathrm{M}$ guanidine hydrochloride (Sigma-Aldrich, St. Louis MO, USA) with $0.5 \mathrm{M}$ potassium phosphate ( $\mathrm{pH} 2.5$ ) and incubated at room temperature for $10 \mathrm{~min}$. After centrifugation $\left(10,000 \times g, 4{ }^{\circ} \mathrm{C}, 10 \mathrm{~min}\right)$, the absorbance of the supernatant was measured at $375 \mathrm{~nm}$ with a spectrophotometer [55]. The concentration of carbonyls was calculated from the molar extinction coefficient for DNPH, $\varepsilon 375=22.000 \mathrm{M}^{-1} \mathrm{~cm}^{-1}$.

\subsection{Determination of Proteasomal Activity}

First, $10 \mu \mathrm{L}$ of protein extract was incubated at $37{ }^{\circ} \mathrm{C}$ for $60 \mathrm{~min}$ with $90 \mu \mathrm{L}$ of $50 \mu \mathrm{M}$ succinyl-Leu-Leu-Val-Tyr-7-amido-4-methylcoumarin (Suc-LLVY-AMC; Sigma-Aldrich, St. Louis MO, USA) dissolved in $80 \mathrm{mM}$ potassium phosphate ( $\mathrm{pH}$ 7.0) under darkness. To determine the specific proteasomal activity, $10 \mu \mathrm{M}$ MG132 (Carbobenzoxy-L-leucyl-L-leucyl-L-leucinal; Sigma-Aldrich, St. Louis MO, USA) dissolved in DMSO was used in parallel during the incubation. The reaction was stopped by adding $0.3 \mathrm{~mL}$ of $80 \mathrm{mM}$ sodium acetate ( $\mathrm{pH} 4.3)$. Released AMC was monitored by fluorescence using FLUOstar Optima Microplate Reader (BMG Labtech, Ortenberg, Germany). The excitation and emission wavelengths were 380 and $440 \mathrm{~nm}$, respectively. Data were plotted in relative fluorescence units (RFU) per protein content of each fraction [56].

\subsection{Determination of Protease Activity}

First, $50 \mu \mathrm{L}$ of protein extract was incubated in $650 \mu \mathrm{L}$ of potassium phosphate buffer ( $\mathrm{pH}$ 5.5) and $0.3 \mathrm{~mL}$ of $1 \%$ azocasein $\left(w / v\right.$ in $0.1 \mathrm{~N} \mathrm{NaOH}$; Sigma-Aldrich, St. Louis MO, USA) for $2 \mathrm{~h}$ at $37^{\circ} \mathrm{C}$ in dark. The reaction was stopped by adding $300 \mu \mathrm{L}$ of $10 \%(w / v)$ TCA and left on ice for 20 min. Samples were centrifuged $\left(15,500 \times g, 4{ }^{\circ} \mathrm{C}, 10 \mathrm{~min}\right)$; then, the yellow colour was measured at $440 \mathrm{~nm}$ with a spectrophotometer. One arbitrary unit (AU) of activity was defined as the amount of protein capable of increasing absorbance at $440 \mathrm{~nm}$ by 0.01 [57].

\subsection{Determination of Malondialdehyde (MDA) Content}

First, $100 \mathrm{mg}$ of leaf samples were homogenised with $1 \mathrm{~mL}$ of $0.1 \%$ TCA. Before the centrifugation $\left(11,500 \times g, 4{ }^{\circ} \mathrm{C}, 20 \mathrm{~min}\right) 0.1 \mathrm{~mL}$ of $4 \%$ butylated hydroxytoluene (BHT; Sigma-Aldrich, St. Louis MO, USA) was added to the samples. Then, $0.5 \mathrm{~mL}$ of supernatant was mixed with $2 \mathrm{~mL} 0.5 \%$ thiobarbituric acid (TBA; Sigma-Aldrich, St. Louis MO, USA) dissolved in 20\% TCA, and the mixture was incubated in boiling water for $30 \mathrm{~min}$. The absorbance was measured at $532 \mathrm{~nm}$ and adjusted for non-specific absorbance at $600 \mathrm{~nm}$. Malondialdehyde (MDA) content was calculated using the extinction coefficient of $155 \mathrm{mM}^{-1} \mathrm{~cm}^{-1}$ [58].

\subsection{Determination the Electrolyte Leakage (EL)}

First, $0.1 \mathrm{~g}$ of leaf discs were incubated in $20 \mathrm{~mL}$ of double-distilled water at $25^{\circ} \mathrm{C}$ for $2 \mathrm{~h}$ under darkness. The conductivity in the bathing solution was first determined (C1) with a conductivity meter (HANNA Instruments, Woonsocket, RI, USA); then, the samples were heated at $95^{\circ} \mathrm{C}$ for 40 min and the total conductivity (C2) of the cooled samples was also measured. Relative electrolyte leakage (EL) was expressed as EL $(\%)=(\mathrm{C} 1 / \mathrm{C} 2) \times 100$ [59]. 


\section{Results}

To test the possible effect of JA in UPR signalling, the transcript accumulation of SlBiP chaperon-coding gene was firstly examined after exogenous JA treatments in tomato leaves. It was found that both applied JA concentrations drastically elevated the transcript levels of SlBiP after $6 \mathrm{~h}$ (Figure 1).

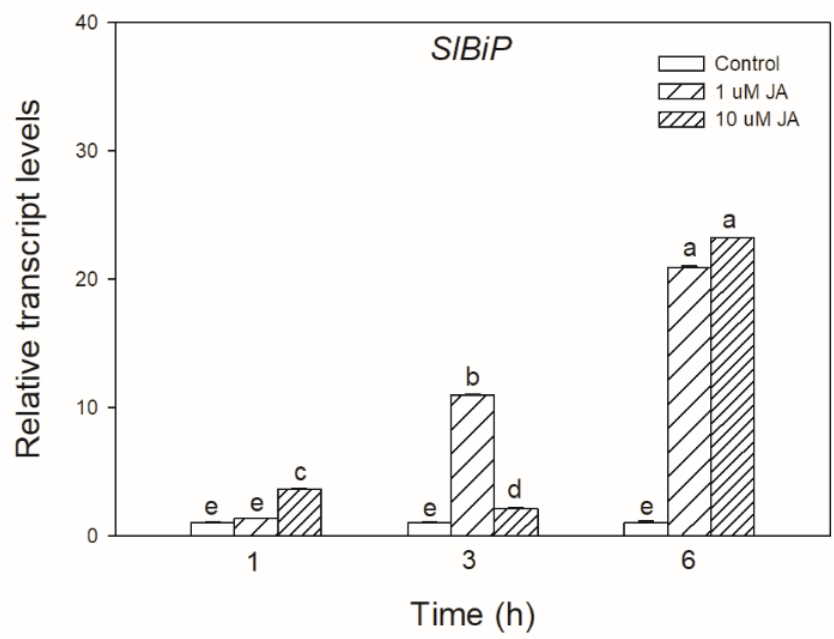

Figure 1. Changes in the transcript accumulation of SlBiP in the leaves of wild-type tomato plants exposed to 1 or $10 \mu \mathrm{M}$ jasmonic acid (JA) for $6 \mathrm{~h}$. Results are the means $\pm \mathrm{SE}$. Data with different letters indicate significant differences at $p<0.05$ level, $n=3$.

Exogenous JA treatment has not only a significant effect on UPR but also could modulate the transcript levels of ER stress signalling components. Significant changes were found in the transcript accumulation of SIIRE1a and SIIRE1b, as well as in the transcript levels of SIbZIP60 upon exogenous JA treatment, which were all elevated after $6 \mathrm{~h}$ in the leaves of tomato plants (Figure 2).

Based on these observations, we were interested in whether JA might play a role in ER stress and UPR in tomato leaves. To detect the effects of JA in these processes, wild-type (WT) and JA signalling mutant (jai1) tomato plants were used. Firstly, changes in the transcript levels of JA marker gene defensin (SIDEF1) were detected. Treatment of the ER stress inducer Tm significantly elevated the amount of transcript in WT leaves (Figure 3). At the same time, the application of chemical chaperon PBA significantly reduced this increment in SIDEF1 transcript levels. The transcription of SIDEF1 in jai1 leaves was not detected (Figure 3).

Quantitative RT-PCR analysis indicated that the transcript accumulation of SlBiP was significantly induced by Tm treatment in WT plants, whereas interestingly, this was significantly lower in jai1 leaves (Figure 4). The accumulation of SlBiP transcripts was suppressed by the use of chemical chaperone PBA in both tomato genotypes, suggesting that Tm treatment was a major cause of the induction of UPR (Figure 4).

Similar effects of these treatments were not observed in the relative transcript accumulation of the coding sequences of ER stress mediator IRE1. The transcript levels of SIIRE1a and SIIRE1b did not change significantly after the 6-h-long Tm treatment in the investigated tomato genotypes but transcript levels of SIIRE1a and SIIRE1b genes were basically lower in jai1 leaves (Figure 5). In contrast to the transcript levels of SIIRE1a and SIIRE1b, the relative transcript levels of SIbZIP60 changed similarly to SlBiP in WT leaves, but it was basically higher in jail compared to WT plants. The accumulation of transcript of SlbZIP60 increased by every treatment in jai1 leaves (Figure 5). 


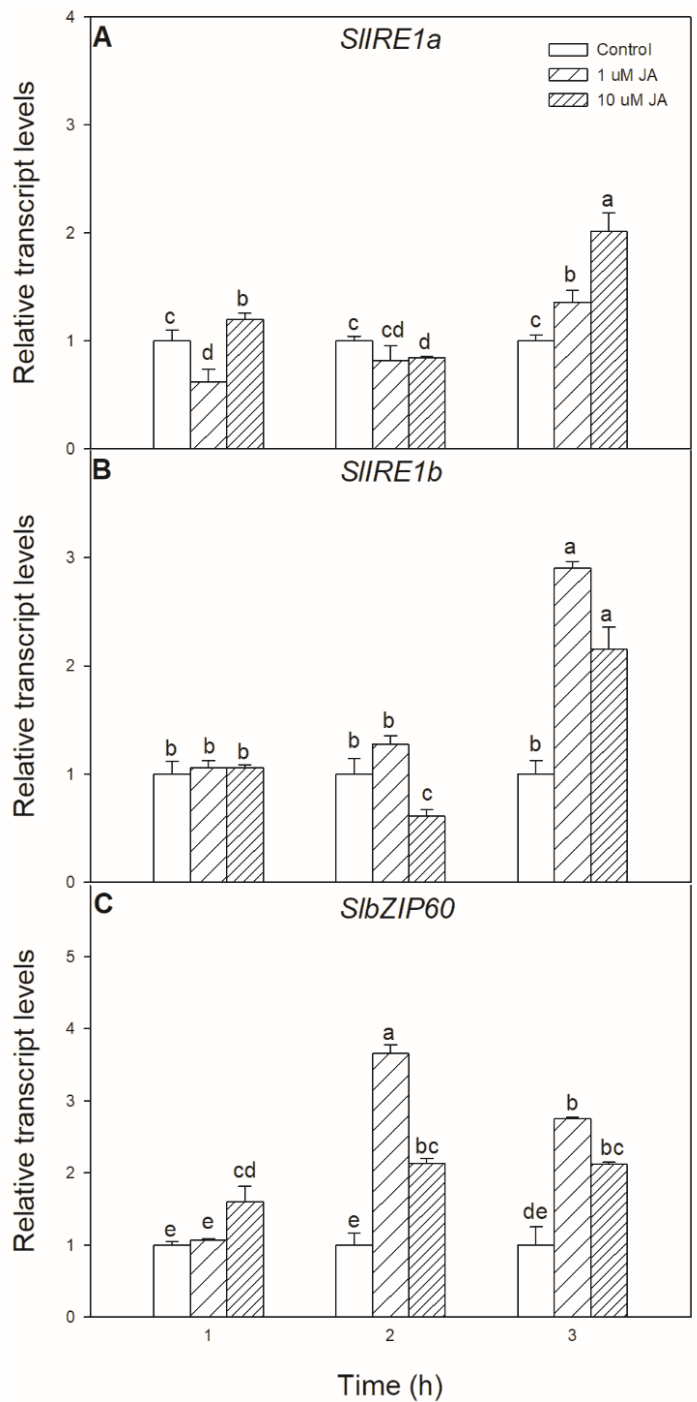

Figure 2. Changes in the transcript accumulation of SIIRE1a (A), SIIRE1b (B), and SIbZIP60 (C) in the leaves of wild-type tomato plants exposed to 1 or $10 \mu \mathrm{M}$ jasmonic acid (JA) for $6 \mathrm{~h}$. Results are the means \pm SE. Data with different letters indicate significant differences at $p<0.05$ level, $n=3$.

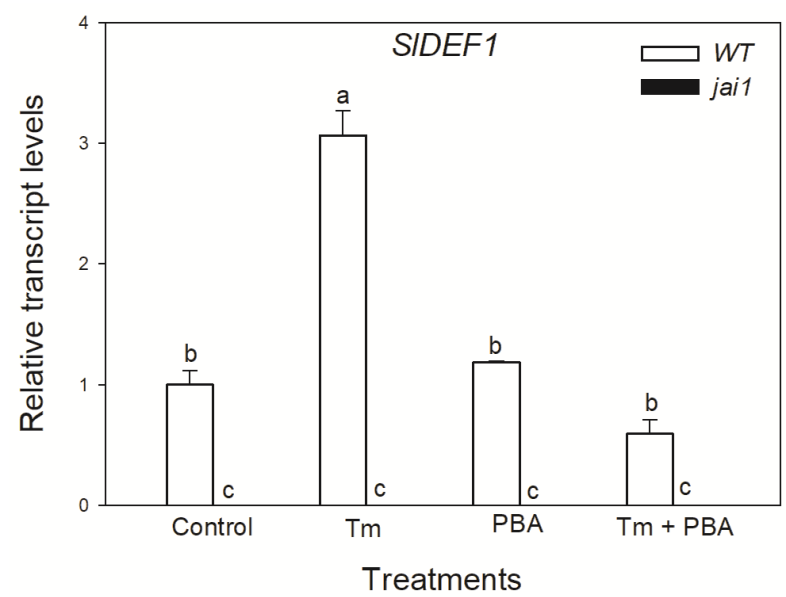

Figure 3. Changes in the transcript accumulation of SIDEF1 in the leaves of wild-type (WT) and JA signalling mutant (jai1) tomato plants exposed to $5 \mu \mathrm{g} \mathrm{mL}{ }^{-1}$ tunicamycin (Tm), $1 \mathrm{mM}$ 4-phenylbutyrate (PBA) and Tm + PBA for $6 \mathrm{~h}$. Results are the means \pm SE. Data with different letters indicate significant differences at $p<0.05$ level, $n=3$. 


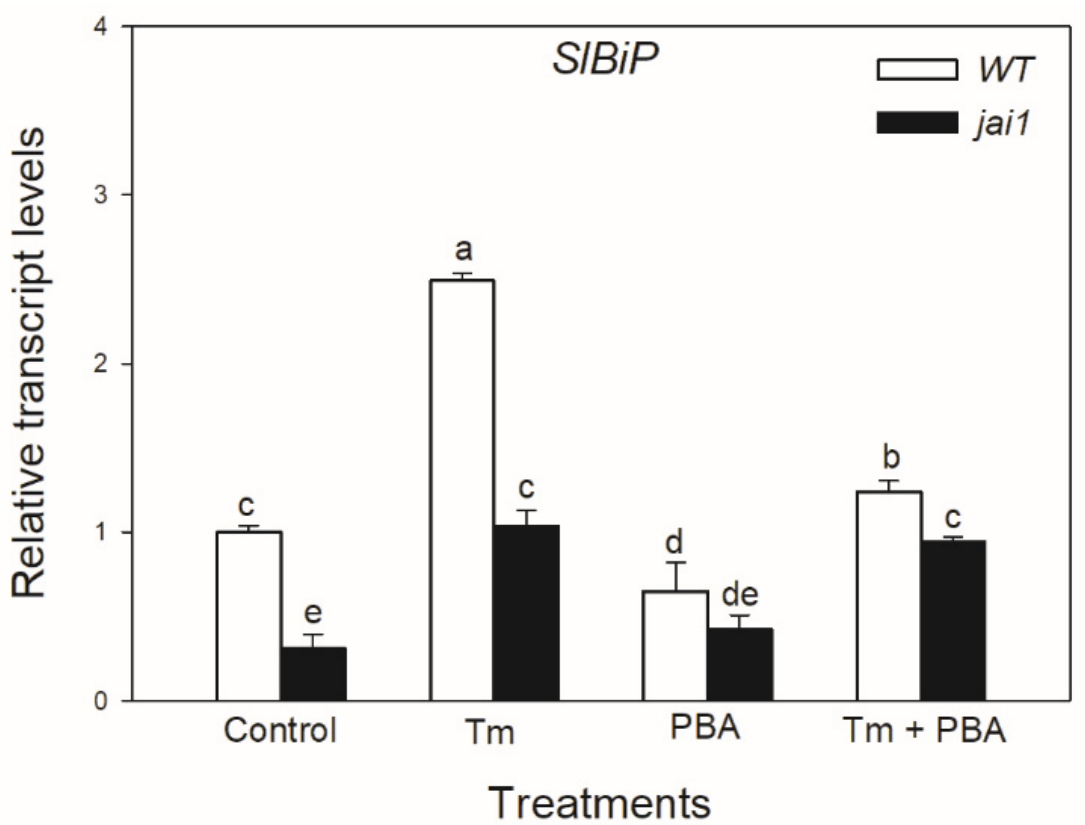

Figure 4. Changes in the transcript accumulation of SlBiP in the leaves of wild-type (WT) and JA signalling mutant (jai1) tomato plants exposed to $5 \mu \mathrm{g} \mathrm{mL}{ }^{-1}$ tunicamycin (Tm), $1 \mathrm{mM}$ 4-phenylbutyrate (PBA), and Tm + PBA for $6 \mathrm{~h}$. Results are the mean \pm SE. Data with different letters indicate significant differences at $p<0.05$ level, $n=3$.

In contrast to the changes in SIIRE1a and SIIRE1b transcripts, the relative transcript levels of SlBI1 changed similarly to SlBiP and SlbZIP60 in WT leaves, Tm increased the accumulation of SlBI1 transcripts, but the combined treatment with PBA decreased it (Figure 5). Interestingly, transcript levels of SIBI1 were basically higher in jai1 compared to WT leaves similarly to SlbZIP60, which were elevated by every treatment (Figure 6).

The potential JA-dependent signalling components were also analysed in the ER-stress response. Significant increase in the $\mathrm{H}_{2} \mathrm{O}_{2}$ level was measured in the Tm-treated WT plants, while it exhibited much moderate increase upon Tm treatment in jai1 leaves (Figure 7A). Application of the combined treatment of Tm + PBA significantly decreased this increment in $\mathrm{H}_{2} \mathrm{O}_{2}$ content (Figure 7A). Interestingly, $\mathrm{H}_{2} \mathrm{O}_{2}$ levels were basically lower in jail compared to WT leaves, similarly to NO production. At the same time, the production of NO changed neither by Tm nor by PBA in the investigated genotypes at this time point (Figure 7B).

The potential effects of oxidative stress generated by Tm on proteins were also investigated. Protein carbonylation did not change significantly after the 6-h-long Tm treatment (Figure 8A), but the chemical chaperone PBA decreased it in jail leaves. In contrast to these findings, Tm increased the relative proteasomal activity in both genotypes, which was significantly declined by the co-application with PBA (Figure 8B). However, the relative proteasomal activity was significantly lower in jail leaves (Figure 8B). At the same time, the total proteolytic activity did not change significantly after $6 \mathrm{~h}$ upon the treatments (Figure 8C).

Lipid peroxidation was measured based on the changes in MDA content. Tm significantly elevated MDA content in WT leaves, but PBA treatment reduced this change (Figure 9A). Interestingly, MDA content did not alter after the treatments of ER stress modulators in jai1 leaves (Figure 9A). Cell death induced by Tm was estimated by the measurement of electrolyte leakage, which did not show any significant differences upon the treatments after $6 \mathrm{~h}$ in the investigated genotypes (Figure 9B). 


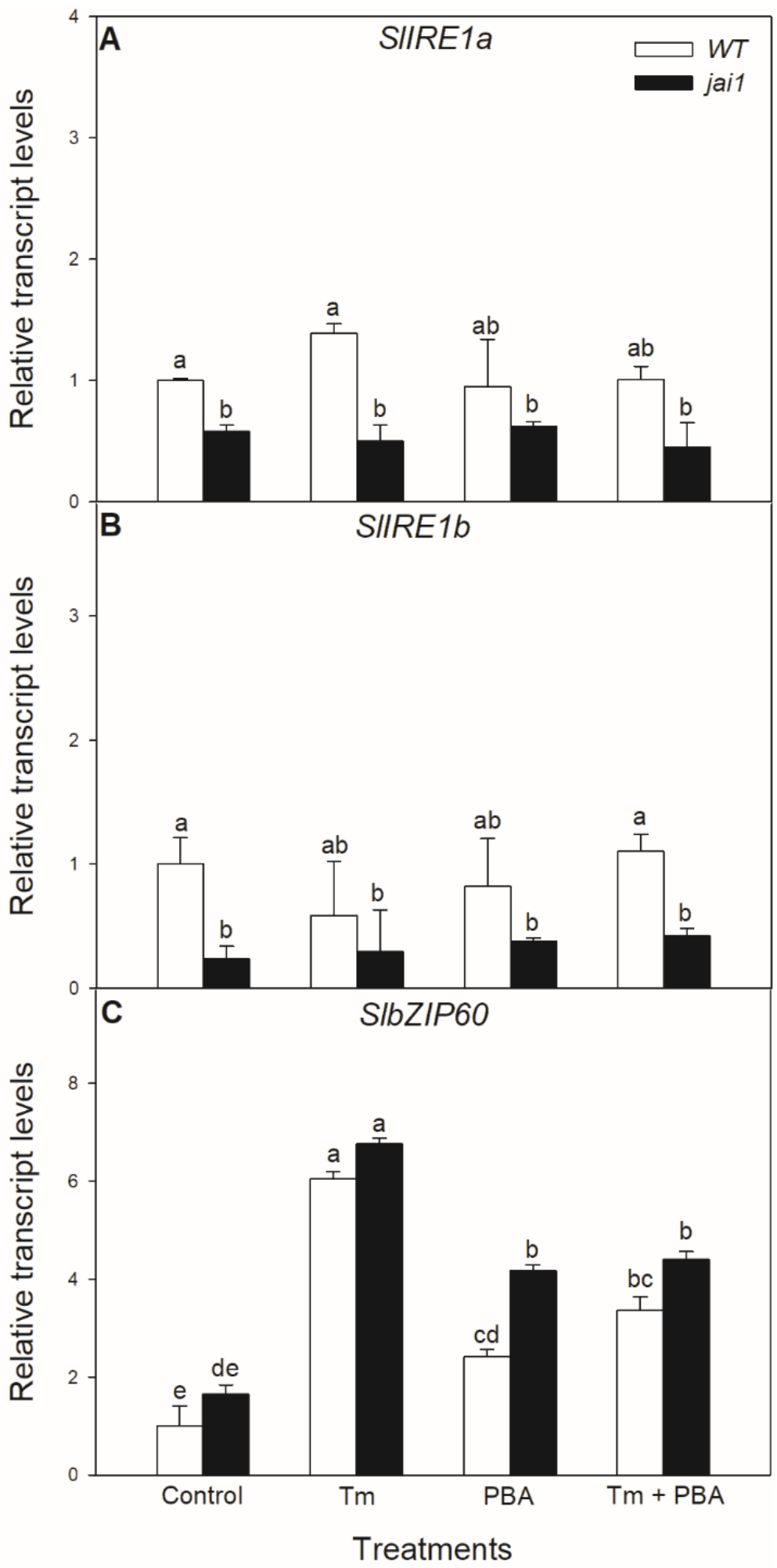

Figure 5. Changes in the transcript accumulation of SIIRE1a (A), SIIRE1b (B) and SlbZIP60 (C) in the leaves of wild-type (WT) and JA signalling mutant (jai1) tomato plants exposed to $5 \mu \mathrm{g} \mathrm{mL} \mathrm{L}^{-1}$ tunicamycin (Tm), $1 \mathrm{mM}$ 4-phenylbutyrate (PBA), and Tm + PBA for $6 \mathrm{~h}$. Results are the means $\pm \mathrm{SE}$. Data with different letters indicate significant differences at $p<0.05$ level, $n=3$. 


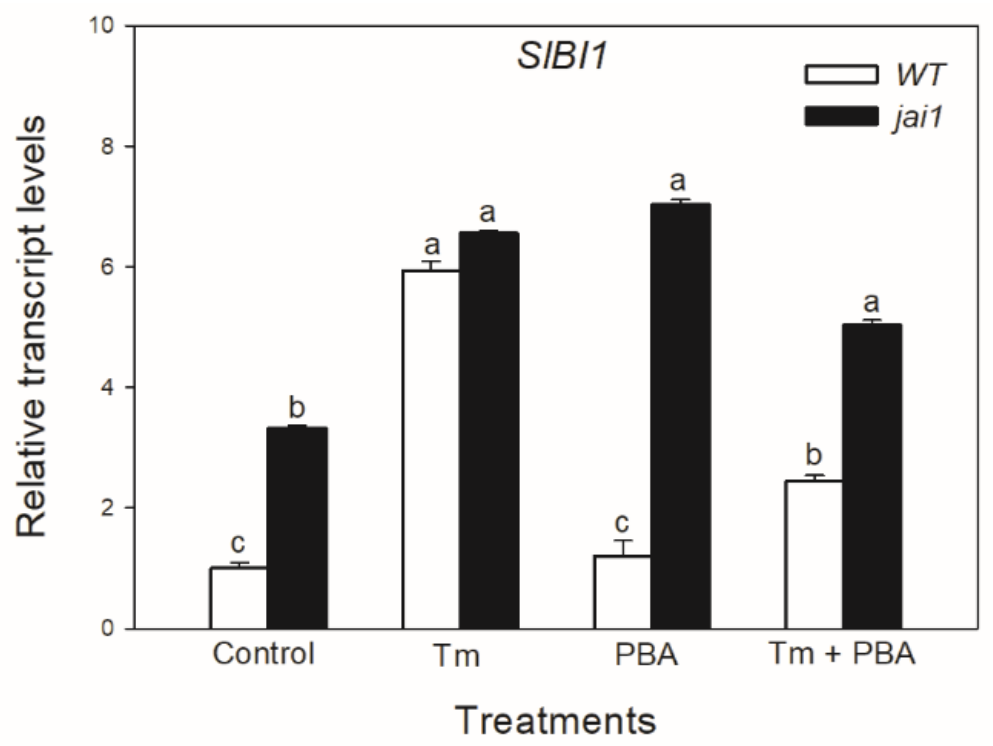

Figure 6. Changes in the transcript accumulation of Bax Inhibitor-1 (SlBI1) in the leaves of wild-type (WT) and JA signalling mutant (jai1) tomato plants exposed to $5 \mu \mathrm{g} \mathrm{mL} \mathrm{L}^{-1}$ tunicamycin (Tm), $1 \mathrm{mM}$ 4-phenylbutyrate (PBA) and Tm + PBA for $6 \mathrm{~h}$. Results are the means $\pm \mathrm{SE}$. Data with different letters indicate significant differences at $p<0.05$ level, $n=3$.

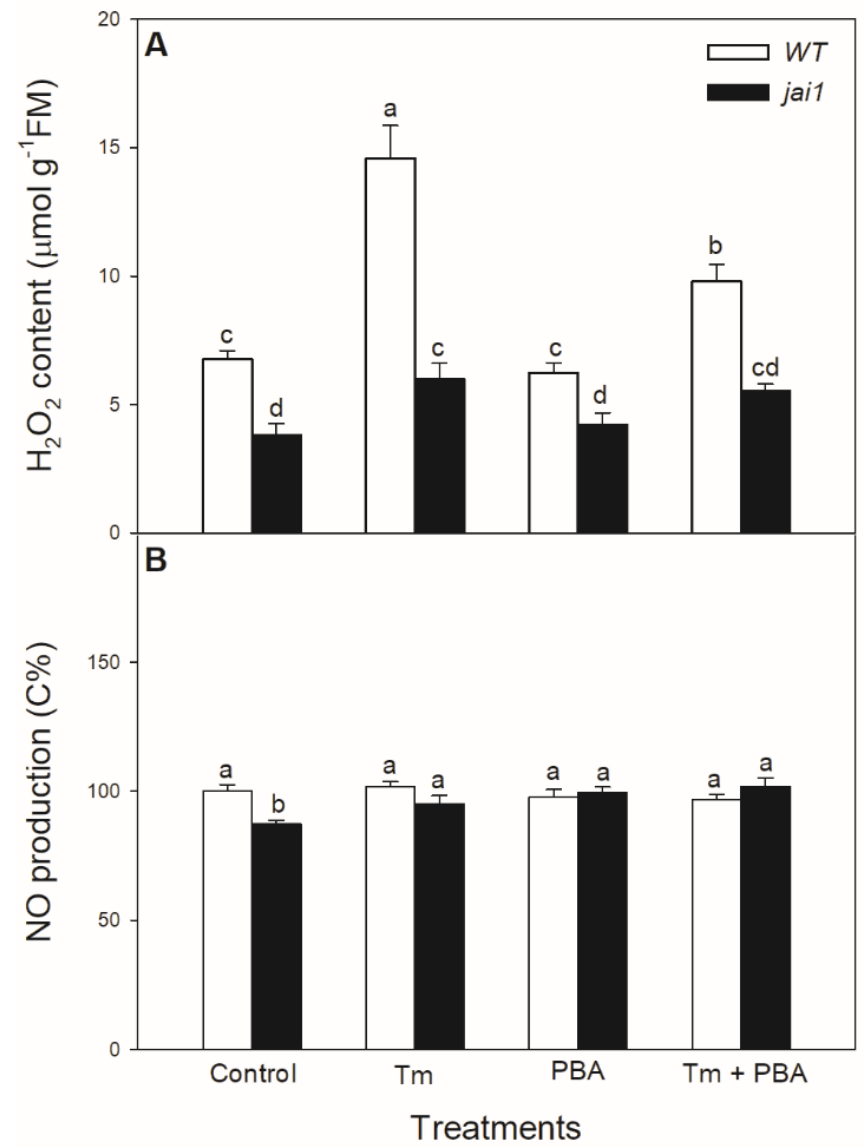

Figure 7. Changes in $\mathrm{H}_{2} \mathrm{O}_{2}$ content (A) and $\mathrm{NO}$ production (B) in the leaves of wild-type (WT) and JA signalling mutant (jai1) tomato plants exposed to $5 \mu \mathrm{g} \mathrm{mL}{ }^{-1}$ tunicamycin (Tm), $1 \mathrm{mM}$ 4-phenylbutyrate (PBA), and Tm + PBA for $6 \mathrm{~h}$. Results are the means \pm SE. Data with different letters indicate significant differences at $p<0.05$ level, $n=3$. 


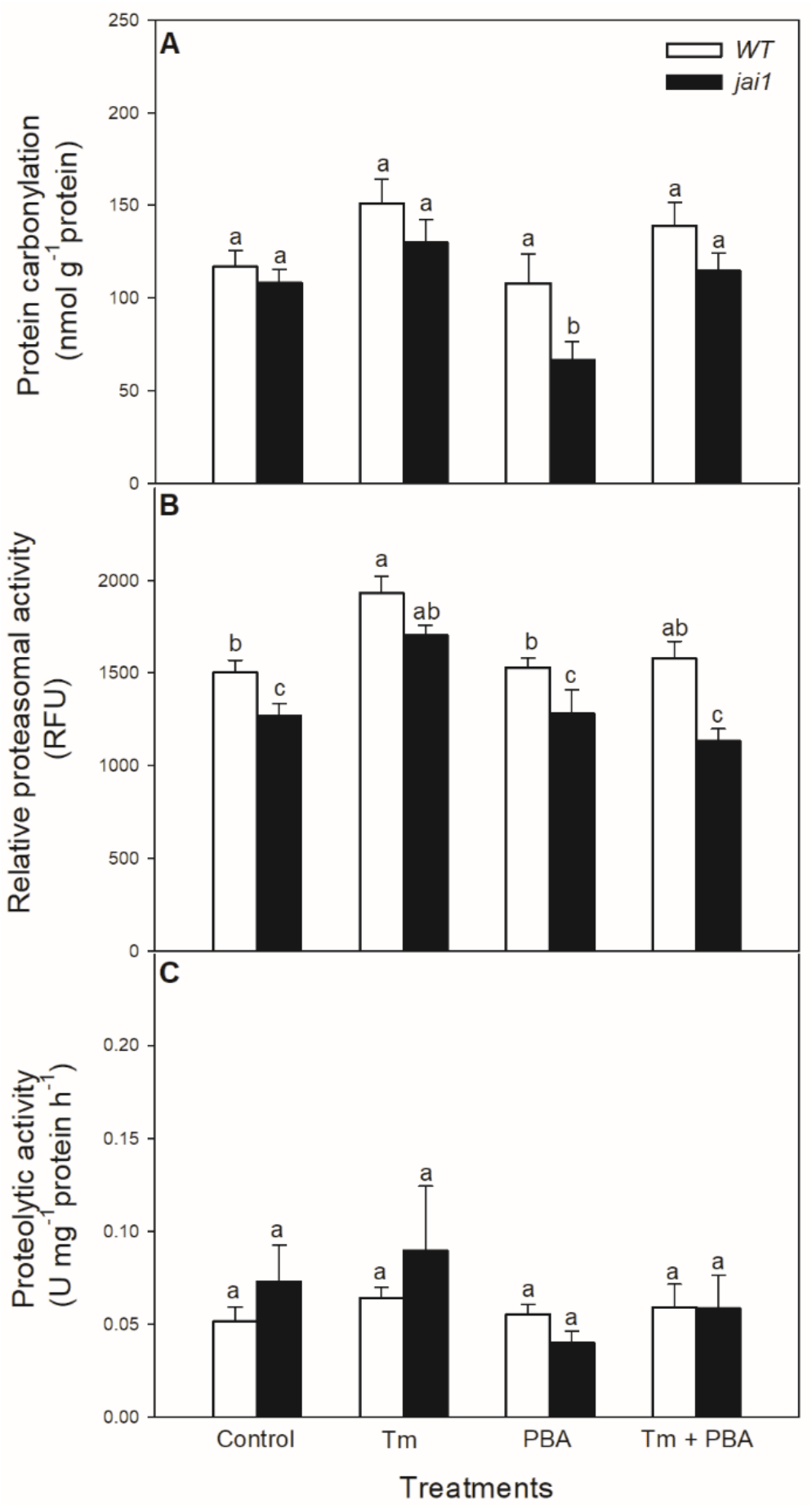

Figure 8. Changes in protein carbonylation (A), proteasomal activity (B), and total proteolytic activity (C) in the leaves of wild-type (WT) and JA signalling mutant (jai1) tomato plants exposed to $5 \mu \mathrm{g} \mathrm{mL}^{-1}$ tunicamycin (Tm), $1 \mathrm{mM}$ 4-phenylbutyrate (PBA), and Tm + PBA for $6 \mathrm{~h}$. Results are the means \pm SE. Data with different letters indicate significant differences at $p<0.05$ level, $n=3$. 


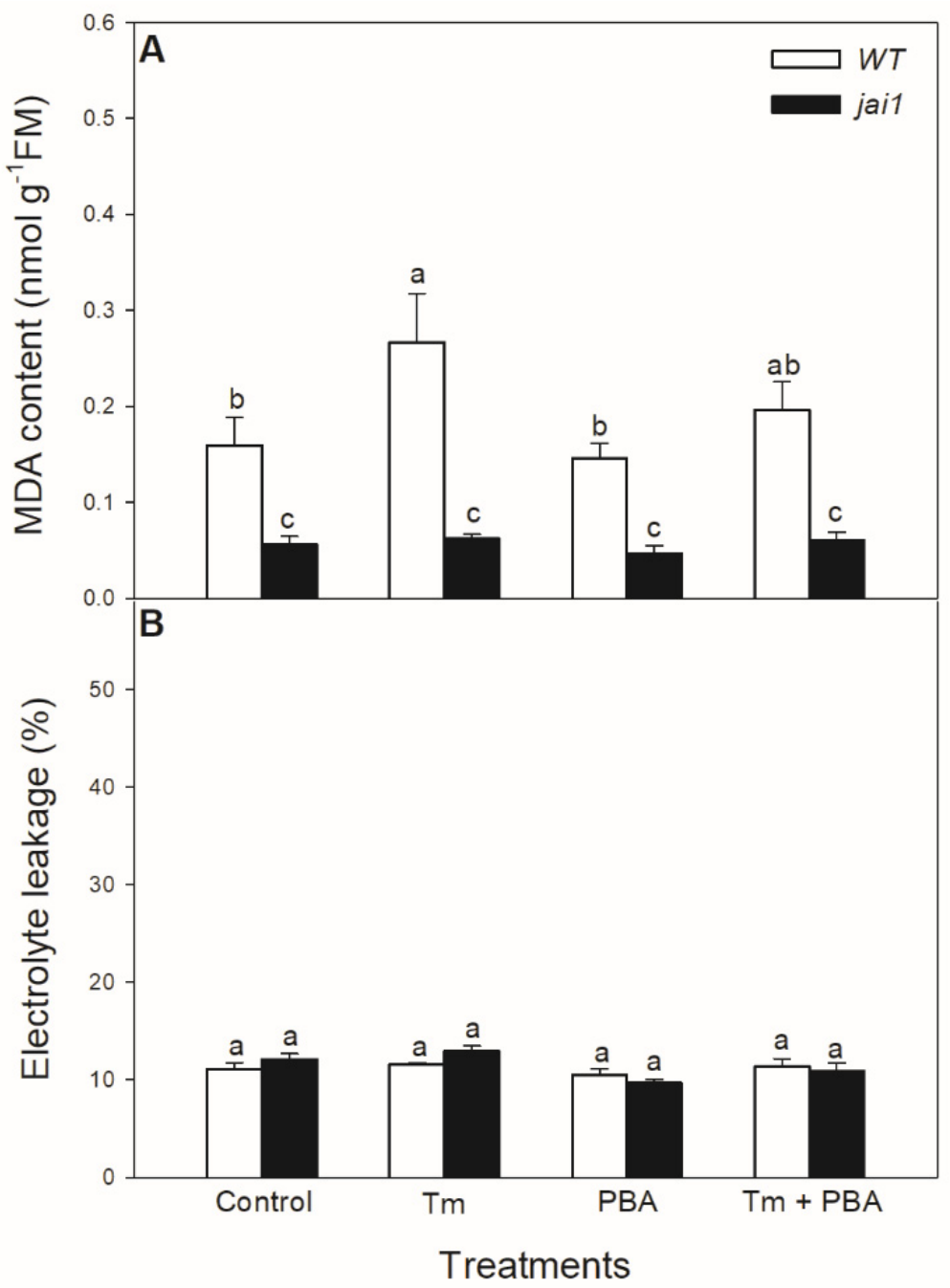

Figure 9. Changes in malondialdehyde (MDA) content (A) and electrolyte leakage (B) from the leaves of wild-type (WT) and JA signalling mutant (jai1) tomato plants exposed to $5 \mu \mathrm{g} \mathrm{mL}{ }^{-1}$ tunicamycin (Tm), $1 \mathrm{mM}$ 4-phenylbutyrate (PBA), and Tm + PBA for $6 \mathrm{~h}$. Results are the means \pm SE. Data with different letters indicate significant differences at $p<0.05$ level, $n=3$.

\section{Discussion}

Despite the fact that the molecular mechanism of ER stress and UPR has been intensively studied in the past years, there are many gaps in comprehending the interaction of ER stress signalling and response mediated by several phytohormones such as JA. It is well-known that JA regulates many processes in plant cells such as defence hormone biosynthesis, nucleic acid metabolism, lipid metabolism, and sugar metabolism, photosynthesis, senescence, and the activation of transporters or kinases [60]. At the same time, there are many results in transcriptome analysis which confirmed that JA plays a crucial role in ROS metabolism, proteasome, and protease activities, as well as chaperon synthesis in various plant species [60-64], suggesting the key role of JA in UPR. In this study, we investigated for the first time the potential role and effects of JA in ER stress and UPR in the cultivated, intact tomato plants based on the analysis of transcript levels of selected marker genes using qRT-PCR [30,33]. The physiological effects of the application of ER stress-inducing agent Tm and changes in JA-dependent signalling components are also the focus of our investigations.

JA plays critical role in protecting plants from various pathogens or insects and in limiting damage from several abiotic stressors [34-37]. Rapid changes in JA levels in the infected or damaged organs could be crucial for the plants to survive $[35,38,39]$. Several authors proved that JA accumulation 
and JA-mediated gene expression occur within several hours after the pathogen infection [65-68]. The results of Pozo et al. [69] showed the transcript levels of the JA marker Lipoxygenase2 (LOX2) started to rise at $1 \mathrm{~h}$ after exogenous $50 \mathrm{mM}$ MeJA treatment and reached the maximum at $6 \mathrm{~h}$, but it significantly decreased after $12 \mathrm{~h}$. Based on these observations, the effects of JA at the $6^{\text {th }}$ hour were selected to investigate the physiological role of JA under ER stress in more detail. Moreover, this time is enough to effectively induce ER stress and UPR in plants e.g., in the case of SA [43,70,71]. JA and its derivatives induce the production of a wide range of antifungal proteins such as defensins or protease inhibitors, as well as activate defence enzymes related to phytoalexin synthesis, such as chalcone synthase, phenylalanine ammonia-lyase, and hydroxymethylglutaryl-coenzyme A reductase [37,40]. Fast and optimal coordination of the expression or the regulation of protein secretory machinery is required to ensure the folding, modification, and transport of proteins, which are mediated by JA similarly to SA $[4,29,70]$. UPR is dependent on molecular chaperones such as BiPs, which are the key components responsible for protein folding, assembly, translocation, and degradation under normal and stress conditions [72,73]. Our results showed that the micromolar concentration of exogenous JA significantly induced the transcript accumulation of BiP within $6 \mathrm{~h}$ in the leaves of tomato plants. This could have great importance because earlier, it has been found only that the exogenous application of JA or SA in millimolar concentration increased the expression of BiP genes in Arabidopsis [33] or in soybean [30]. In this work, JA was applied in two different micromolar concentrations, which could be closer to the natural endogenous changes in plants upon pathogen infection [74,75]. Moreover, it can be described the first time that the effects of different concentrations of JA showed time-dependent changes on SlBiP transcription, which can be related to the concentration-dependent transport and signalling of JA similarly to SA $[32,76]$. Similar to this, it has been also observed that the transcript levels of BiP were varied and not linearly elevated by TM as a function of time [77]. In addition, both exogenous JA treatments induced the transcript accumulation of the coding sequences of ER stress sensor IRE1 and UPR-activating transcription factor bZIP60 in tomato, suggesting that JA not only plays a role in UPR, but it has also a significant effect on ER stress signalling components. Unfortunately, only IRE1 and bZIP60 have been identified clearly in the tomato genome among the ER stress signalling components described in Arabidopsis [49], and the precise identification of other components (e.g., bZIPs, NACs) in this process is required to understand the complex molecular mechanism of ER stress sensing and signalling in tomato.

Our results provide evidence for the first time that exogenous JA can generate ER stress and UPR in tomato. The potential role of JA in these processes was further analysed by WT and JA signalling mutant (jai1) tomato plants. To test the potential role of JA in UPR, the exogenous application of several chemicals such as Tm, the inhibitor of N-glycosylation of secreted glycoproteins, and the chemical chaperon PBA were used. These modulators have been applied extensively under laboratory conditions [14]. Earlier, it was found that the application of Tm induced ER stress within $2 \mathrm{~h}$ in Arabidopsis leaves [42], and $1 \mathrm{mM}$ PBA was able to significantly reduce it [47]. Our results demonstrate that Tm induced the accumulation of JA marker gene defensin (SIDEF1) in WT leaves, which was inhibited by the application of PBA. These changes in transcripts of SIDEF1 could confirm that Tm induced JA signalling in the leaves of WT tomato plants. In addition, Tm also significantly induced the transcript accumulation of SlBiP in WT plants, which was significantly lower in jai1 leaves, suggesting a significant role of JA in UPR. The accumulation of SlBiP transcript was suppressed by PBA in both tomato genotypes, indicating that Tm treatment was a major cause of the induction of UPR. The close relationship between BiP chaperone, JA, and other defence hormones was confirmed recently in BiP-overexpressing transgenic soybean plants, where the JA content was lower compared to the WT under control conditions [41]. Others also found that JA plays a role in the induction of various chaperon-coding sequences in different plant species [60,61]. While the transcript levels of SIIRE1a and SIIRE1b did not change significantly at this time point after Tm treatment in none of the tomato genotypes, the transcript levels of both ER stress sensor genes were basically lower in jai1 leaves, suggesting a principal role of JA in the regulation of IRE. At the same time, the insignificant changes in 
the transcript accumulation of IRE1 did not show the JA-mediated activity of IRE1 after Tm treatment in WT. Moreover, the transcript accumulation of these genes could be also dependent on the time similarly to the results measured in the case of exogenous JA treatments. It can be concluded that describing the direct effects of JA on the molecular mechanism of ER stress sensing and signalling needs further research in tomato. In contrast to the results of SIIRE1 transcription, the transcript accumulation of SlbZIP60 changed similarly to SIBiP, but transcript levels of SlbZIP60 were higher in jai1 leaves. These results showed that Tm induced the transcript accumulation of SlbZIP60, but this was independent on JA based on the measurements in jai1. Two copies of IRE1, IRE1a and IRE1b, can be found in Arabidopsis with diverse function under ER stress. IRE1a is required for bZIP60 splicing upon pathogen infection, while IRE1b plays a role in bZIP60 processing upon Tm-induced ER stress [42]. In tomato, further studies are needed to explore the adequate role of the two IRE1 sequences and IRE1-mediated bZIP60 pathway under ER stress and UPR. Moreover, further research studies are required to identify other signalling components of ER stress and UPR in tomato, which could be different compared to Arabidopsis.

Surprisingly, in contrast to SIIRE1a and SIIRE1b but similarly to SlbZIP60, the relative transcript levels of SlBI1 were basically higher in jail compared to WT leaves. Treatment with Tm increased the transcript accumulation of SlBI1 but the combined treatment with PBA decreased it; these changes were more pronounced in jai1 leaves, suggesting the inhibitory effects of JA on SlBI1 under ER stress. It is known that BI1 is involved in the inhibition of PCD in Arabidopsis by decreasing the ER stress-induced ROS production or by regulating $\mathrm{Ca}^{2+}$ homeostasis $[47,78]$. Moreover, BI1 can increase resistance to necrotrophic pathogens controlled by JA [79]. Elevated JA content and the up-regulation of JAand SA-related genes at the initial and/or late stages of the infection may suppress the anti-cell death mechanism. In contrast to this, the exogenous application of SA induced the transcript accumulation of SlBI1 in a concentration-dependent manner [80]. It was also found that over-expression of the AtBI1 gene delayed the onset of MeJA-induced leaf senescence in Arabidopsis, suggesting a complex relationship between BI1 and JA [81].

The potential role of JA-dependent signalling components such as $\mathrm{H}_{2} \mathrm{O}_{2}$ and $\mathrm{NO}$ was also analysed in the ER stress response. It has been shown earlier that there is a tight association between ROS and ER stress [7,82]. $\mathrm{H}_{2} \mathrm{O}_{2}$ is the most stable ROS, which can act both as a toxic compound (inducing oxidative stress and cell death by oxidizing proteins and increasing lipid peroxidation) or as a signalling molecule (mediating tolerance by inducing antioxidant enzymes) in a concentration-dependent manner [83-85]. There is also a close interaction between ROS/NO signalling and JA $[40,86,87]$. It has been shown that elicitor treatment or wounding trigger ROS production through NADPH oxidase activation can induce the expression of JA biosynthesis genes [88,89]. In addition, ROS accumulation is required for JA-induced stomatal closure in Arabidopsis [90,91]. We also measured a significant increase in $\mathrm{H}_{2} \mathrm{O}_{2}$ after the treatment with Tm similarly to another research group [43], but we observed for the first time that $\mathrm{H}_{2} \mathrm{O}_{2}$ levels stayed significantly lower in jail compared to WT leaves, suggesting the role of JA in controlling ER stress sensing and signalling. The application of PBA together with Tm was able to decrease this increment in $\mathrm{H}_{2} \mathrm{O}_{2}$ content. Interestingly, $\mathrm{H}_{2} \mathrm{O}_{2}$ levels were basically lower in jai1 compared to WT leaves. Similarly to our result, lower $\mathrm{H}_{2} \mathrm{O}_{2}$ content was measured in defenseless-1 (def-1) JA-deficient tomato mutant compared to WT plants [92]. NO is also an important signal molecule involved in multiple plant physiological processes $[93,94]$. It was earlier found that NO contributes positively to elicit the production of jasmonates [95] and JA enhances NO synthesis in guard cells [91]. At the same time, NO production did not change after treatments of Tm and PBA in intact leaves in either of the tomato genotypes, suggesting that it is not a component of ER stress signalling and UPR at this time point after the treatments in tomato leaves.

High concentrations of ROS can induce the accumulation of oxidized proteins [83]. To avoid their toxic accumulation, carbonylated proteins are degraded through the action of the $26 \mathrm{~S}$ proteasome in the cytosol [96]. It was earlier described that Tm significantly elevated $\mathrm{H}_{2} \mathrm{O}_{2}$ levels and increased protein carbonylation but only after $48 \mathrm{~h}$ in Arabidopsis [43]. Based on our observation, protein 
carbonylation did not change significantly after the 6-h-long Tm treatment but elevated slightly in WT leaves. Interestingly, PBA treatment significantly decreased it in jai1 leaves. In contrast to protein carbonylation, the ER stress generator Tm elevated the relative proteasomal activity in both tomato genotypes, which was significantly suppressed by the addition of PBA. At the same time, proteasomal activity was significantly lower in jail leaves, suggesting a role of JA in the coordinated degradation of oxidized proteins. However, total proteolytic activity, which is elevated under cell death induction by ER stress or immune response [10,97,98], did not change after the 6-h-long treatment of ER stress modulators in intact leaves of tomato plants. Based on the results, it can be concluded that only the regulated proteolytic activity was initiated, and cell death was not promoted at this time point.

At the same time, lipid peroxidation is elevated by Tm treatment in the leaves of tomato, as it was shown in the measurement of MDA content. The application of PBA could reduce this increment in MDA level upon Tm treatment. This is in good accordance with the earlier result in Arabidopsis, where significantly higher lipid peroxidation was also measured, following the Tm treatment [43]. Interestingly, MDA content did not change after the treatments of ER stress modulators in jai1 leaves, suggesting the role of JA in ER stress-induced oxidative burst sensing and signalling. Similarly to our results, JA-deficient defenseless-1 (def-1) mutant tomato showed basically lower MDA content compared to WT plants [92]. In contrast to the elevated MDA content, cell membranes remained intact upon $\mathrm{Tm}$ treatments and cell death was not initiated during the $6 \mathrm{~h}$-long Tm treatment in the leaves of neither tomato genotypes based on the results of the electrolyte leakage measurements.

\section{Conclusions}

Our results confirmed the first time that JA plays a role in ER stress sensing and signalling in intact tomato plants. Exogenous JA not only induces the transcript accumulation of UPR marker gene SlBiP but also elevates the transcript levels of ER stress sensor SIIRE1 and the UPR-related basic transcription factor SlbZIP60 after $6 \mathrm{~h}$, but these changes were concentration- and time-dependent, respectively. It was the first time when the role of JA in Tm-induced ER stress and UPR was investigated in jai1 tomato plants, which are defective in JA signalling. Tm induced significant transcript accumulation in SlBiP, SlbZIP60, and SlBI1, which was dependent on JA based on the measurements in jai1 leaves. We found at the first time that $\mathrm{H}_{2} \mathrm{O}_{2}$ content, proteasomal activity, and lipid peroxidation induced by $\mathrm{Tm}$ is regulated by JA, while NO seems to be uninvolved in ER stress and UPR signalling at this time point in tomato leaves. Our results suggested the first time the significant physiological effects of JA in ER stress and UPR in tomato leaves, but the concrete molecular mechanism of JA in ER stress and UPR needs further research.

Author Contributions: Conceptualization, I.T. and P.P.; Investigation, Z.C., O.C., A.Ö., P.P.; Writing-original draft preparation, Z.C. and P.P.; Writing - review and editing, Z.C., A.Ö., I.T. and P.P. All authors have read and agreed to the published version of the manuscript.

Funding: This work was supported by the grants from the National Research, Development and Innovation Office of Hungary-NKFIH (Grant no. OTKA PD112855 and NKFIH FK 124871) and by the UNKP-18-3-I-SZTE-17 and the UNKP-19-4-SZTE-86 New National Excellence Program of the Ministry of Human Capacities and the University of Szeged Open Access Fund (4718). Péter Poór was supported by the János Bolyai Research Scholarship of the Hungarian Academy of Sciences.

Acknowledgments: We thank Bécs Attiláné for her excellent technical assistance.

Conflicts of Interest: The authors declare no conflict of interest.

\section{References}

1. Liu, J.X.; Howell, S.H. Endoplasmic reticulum protein quality control and its relationship to environmental stress responses in plants. Plant Cell 2010, 22, 2930-2942. [CrossRef] [PubMed]

2. Kørner, C.; Du, X.; Vollmer, M.; Pajerowska-Mukhtar, K. Endoplasmic reticulum stress signaling in plant immunity-At the crossroad of life and death. Int. J. Mol. Sci. 2015, 16, 26582-26598. [CrossRef] [PubMed] 
3. Verchot, J. How does the stressed out ER find relief during virus infection? Curr. Opin. Virol. 2016, 17, 74-79. [CrossRef] [PubMed]

4. Nawkar, G.M.; Lee, E.S.; Shelake, R.M.; Park, J.H.; Ryu, S.W.; Kang, C.H.; Lee, S.Y. Activation of the transducers of unfolded protein response in plants. Front. Plant Sci. 2018, 9, 214. [CrossRef] [PubMed]

5. Liu, Y.; Li, J. Endoplasmic reticulum-mediated protein quality control in Arabidopsis. Front. Plant Sci. 2014, $5,162$.

6. Chakraborty, R.; Baek, J.H.; Bae, E.Y.; Kim, W.Y.; Lee, S.Y.; Kim, M.G. Comparison and contrast of plant, yeast, and mammalian ER stress and UPR. Appl. Biol. Chem. 2016, 59, 337-347. [CrossRef]

7. Ozgur, R.; Uzilday, B.; Iwata, Y.; Koizumi, N.; Turkan, I. Interplay between the unfolded protein response and reactive oxygen species: A dynamic duo. J. Exp. Bot. 2018, 69, 3333-3345. [CrossRef]

8. Schäfer, P.; Eichmann, R. The endoplasmic reticulum in plant immunity and cell death. Front. Plant Sci. 2012, 3, 200.

9. $\mathrm{Pu}, \mathrm{Y}$.; Bassham, D.C. Links between ER stress and autophagy in plants. Plant Signal. Behav. 2013, 8, e24297. [CrossRef]

10. Cai, Y.; Yu, J.; Gallois, P. Endoplasmic reticulum stress-induced PCD and caspase-like activities involved. Front. Plant Sci. 2014, 5, 41. [CrossRef]

11. Wan, S.; Jiang, L. Endoplasmic reticulum (ER) stress and the unfolded protein response (UPR) in plants. Protoplasma 2016, 253, 753-764. [CrossRef] [PubMed]

12. Park, C.J.; Park, J.M. Endoplasmic reticulum plays a critical role in integrating signals generated by both biotic and abiotic stress in plants. Front. Plant Sci. 2019, 10, 399. [CrossRef] [PubMed]

13. Iwata, Y.; Koizumi, N. Plant transducers of the endoplasmic reticulum unfolded protein response. Trends Plant Sci. 2012, 17, 720-727. [CrossRef] [PubMed]

14. Howell, S.H. Endoplasmic reticulum stress responses in plants. Annu. Rev. Plant Biol. 2013, 64, 477-499. [CrossRef] [PubMed]

15. Liu, J.X.; Howell, S.H. Managing the protein folding demands in the endoplasmic reticulum of plants. New Phytol. 2016, 211, 418-428. [CrossRef] [PubMed]

16. Mishiba, K.I.; Nagashima, Y.; Suzuki, E.; Hayashi, N.; Ogata, Y.; Shimada, Y.; Koizumi, N. Defects in IRE1 enhance cell death and fail to degrade mRNAs encoding secretory pathway proteins in the Arabidopsis unfolded protein response. Proc. Natl. Acad. Sci. USA 2013, 110, 5713-5718. [CrossRef]

17. Zhang, L.; Chen, H.; Brandizzi, F.; Verchot, J.; Wang, A. The UPR branch IRE1-bZIP60 in plants plays an essential role in viral infection and is complementary to the only UPR pathway in yeast. PLoS Genet. 2015, 11, e1005164. [CrossRef]

18. Zhang, L.; Zhang, C.; Wang, A. Divergence and conservation of the major UPR branch IRE1-bZIP signaling pathway across eukaryotes. Sci. Rep. 2016, 6, 27362. [CrossRef]

19. Afrin, T.; Diwan, D.; Sahawneh, K.; Pajerowska-Mukhtar, K. Multilevel regulation of endoplasmic reticulum stress responses in plants: Where old roads and new paths meet. J. Exp. Bot. 2020, 71, 1659-1667. [CrossRef]

20. Liu, J.X.; Srivastava, R.; Che, P.; Howell, S.H. An endoplasmic reticulum stress response in Arabidopsis is mediated by proteolytic processing and nuclear relocation of a membrane-associated transcription factor, bZIP28. Plant Cell 2007, 19, 4111-4119. [CrossRef]

21. Srivastava, R.; Chen, Y.; Deng, Y.; Brandizzi, F.; Howell, S.H. Elements proximal to and within the transmembrane domain mediate the organelle-to-organelle movement of bZIP28 under ER stress conditions. Plant J. 2012, 70, 1033-1042. [CrossRef] [PubMed]

22. Srivastava, R.; Deng, Y.; Shah, S.; Rao, A.G.; Howell, S.H. BINDING PROTEIN is a master regulator of the endoplasmic reticulum stress sensor/transducer bZIP28 in Arabidopsis. Plant Cell 2013, 25, 1416-1429. [CrossRef] [PubMed]

23. Srivastava, R.; Deng, Y.; Howell, S.H. Stress sensing in plants by an ER stress sensor/transducer, bZIP28. Front. Plant Sci. 2014, 5, 59. [CrossRef] [PubMed]

24. Iwata, Y.; Ashida, M.; Hasegawa, C.; Tabara, K.; Mishiba, K.I.; Koizumi, N. Activation of the Arabidopsis membrane-bound transcription factor bZIP 28 is mediated by site-2 protease, but not site- 1 protease. Plant J. 2017, 91, 408-415. [CrossRef]

25. Li, Y.; Williams, B.; Dickman, M. Arabidopsis B-cell lymphoma2 (Bcl-2)-associated athanogene 7 (BAG7)-mediated heat tolerance requires translocation, sumoylation and binding to WRKY29. New Phytol. 2017, 214, 695-705. [CrossRef] 
26. Liu, J.X.; Srivastava, R.; Che, P.; Howell, S.H. Salt stress responses in Arabidopsis utilize a signal transduction pathway related to endoplasmic reticulum stress signaling. Plant J. 2007, 51, 897-909. [CrossRef]

27. Liu, J.X.; Srivastava, R.; Howell, S.H. Stress-induced expression of an activated form of AtbZIP17 provides protection from salt stress in Arabidopsis. Plant Cell Environ. 2008, 31, 1735-1743. [CrossRef]

28. Fragkostefanakis, S.; Mesihovic, A.; Hu, Y.; Schleiff, E. Unfolded protein response in pollen development and heat stress tolerance. Plant Reprod. 2016, 29, 81-91. [CrossRef]

29. Wang, D.; Weaver, N.D.; Kesarwani, M.; Dong, X. Induction of protein secretory pathway is required for systemic acquired resistance. Science 2005, 308, 1036-1040. [CrossRef]

30. Nagashima, Y.; Iwata, Y.; Ashida, M.; Mishiba, K.I.; Koizumi, N. Exogenous salicylic acid activates two signaling arms of the unfolded protein response in Arabidopsis. Plant Cell Physiol. 2014, 55, 1772-1778. [CrossRef]

31. Chen, Y.; Aung, K.; Rolčík, J.; Walicki, K.; Friml, J.; Brandizzi, F. Inter-regulation of the unfolded protein response and auxin signaling. Plant J. 2014, 77, 97-107. [CrossRef] [PubMed]

32. Poór, P.; Czékus, Z.; Tari, I.; Ördög, A. The Multifaceted Roles of Plant Hormone Salicylic Acid in Endoplasmic Reticulum Stress and Unfolded Protein Response. Int. J. Mol. Sci. 2019, 20, 5842. [CrossRef] [PubMed]

33. Xu, Z.; Song, N.; Ma, L.; Wu, J. IRE1-bZIP60 pathway is required for Nicotiana attenuata resistance to fungal pathogen Alternaria alternata. Front. Plant Sci. 2019, 10, 263. [CrossRef] [PubMed]

34. Pozo, M.J.; Van Loon, L.C.; Pieterse, C.M. Jasmonates-signals in plant-microbe interactions. J. Plant Growth Regul. 2004, 23, 211-222.

35. Van der Ent, S.; Van Wees, S.C.; Pieterse, C.M. Jasmonate signaling in plant interactions with resistance-inducing beneficial microbes. Phytochemistry 2009, 70, 1581-1588. [CrossRef]

36. Santino, A.; Taurino, M.; De Domenico, S.; Bonsegna, S.; Poltronieri, P.; Pastor, V.; Flors, V. Jasmonate signaling in plant development and defense response to multiple (a) biotic stresses. Plant Cell Rep. 2013, 32, 1085-1098. [CrossRef]

37. Wasternack, C.; Hause, B. Jasmonates: Biosynthesis, perception, signal transduction and action in plant stress response, growth and development. An update to the 2007 review in Annals of Botany. Ann. Bot. 2013, 111, 1021-1058. [CrossRef]

38. Pieterse, C.M.; Zamioudis, C.; Berendsen, R.L.; Weller, D.M.; Van Wees, S.C.; Bakker, P.A. Induced systemic resistance by beneficial microbes. Annu. Rev. Phytopathol. 2014, 52, 347-375. [CrossRef]

39. Wasternack, C. How jasmonates earned their laurels: Past and present. J. Plant Growth Regul. 2015, 34, 761-794. [CrossRef]

40. Hu, X.; Wansha, L.; Chen, Q.; Yang, Y. Early signals transduction linking the synthesis of jasmonic acid in plant. Plant Signal. Behav. 2009, 4, 696-697. [CrossRef]

41. Coutinho, F.S.; dos Santos, D.S.; Lima, L.L.; Vital, C.E.; Santos, L.A.; Pimenta, M.R.; da Silva, J.C.; Ramos, J.R.L.S.; Mehta, A.; Fontes, E.P.B.; et al. Mechanism of the drought tolerance of a transgenic soybean overexpressing the molecular chaperone BiP. Physiol. Mol. Biol. Plants 2019, 25, 457-472. [CrossRef] [PubMed]

42. Moreno, A.A.; Mukhtar, M.S.; Blanco, F.; Boatwright, J.L.; Moreno, I.; Jordan, M.R.; Chen, Y.; Brandizzi, F.; Dong, X.; Orellana, A.; et al. IRE1/bZIP60-mediated unfolded protein response plays distinct roles in plant immunity and abiotic stress responses. PLoS ONE 2012, 7, e31944. [CrossRef] [PubMed]

43. Ozgur, R.; Turkan, I.; Uzilday, B.; Sekmen, A.H. Endoplasmic reticulum stress triggers ROS signalling, changes the redox state, and regulates the antioxidant defence of Arabidopsis thaliana. J. Exp. Bot. 2014, 65, 1377-1390. [CrossRef]

44. Li, L.; Zhao, Y.; McCaig, B.C.; Wingerd, B.A.; Wang, J.; Whalon, M.E.; Howe, G.A. The tomato homolog of CORONATINE-INSENSITIVE1 is required for the maternal control of seed maturation, jasmonate-signaled defense responses, and glandular trichome development. Plant Cell 2004, 16, 126-143. [CrossRef] [PubMed]

45. Howe, G.A.; Ryan, C.A. Suppressors of systemin signaling identify genes in the tomato wound response pathway. Genetics 1999, 153, 1411-1421.

46. Poór, P.; Kovács, J.; Borbély, P.; Takács, Z.; Szepesi, Á.; Tari, I. Salt stress-induced production of reactive oxygen-and nitrogen species and cell death in the ethylene receptor mutant Never ripe and wild type tomato roots. Plant Physiol. Biochem. 2015, 97, 313-322. [CrossRef] [PubMed]

47. Watanabe, N.; Lam, E. BAX inhibitor-1 modulates endoplasmic reticulum stress-mediated programmed cell death in Arabidopsis. J. Biol. Chem. 2008, 283, 3200-3210. [CrossRef] 
48. Chomczynski, P.; Sacchi, N. Single-step method of RNA isolation by acid guanidinium thiocyanate-phenol-chloroform extraction. Anal. Biochem. 1987, 162, 156-159. [CrossRef]

49. National Center for Biotechnology Information (NCBI). Available online: https://www.ncbi.nlm.nih.gov/ (accessed on 22 May 2020).

50. Takács, Z.; Poór, P.; Borbély, P.; Czékus, Z.; Szalai, G.; Tari, I. $\mathrm{H}_{2} \mathrm{O}_{2}$ homeostasis in wild-type and ethylene-insensitive Never ripe tomato in response to salicylic acid treatment in normal photoperiod and in prolonged darkness. Plant Physiol. Biochem. 2018, 126, 74-85. [CrossRef]

51. Livak, K.J.; Schmittgen, T.D. Analysis of relative gene expression data using real-time quantitative PCR and the $2^{-\Delta \Delta C T}$ method. Methods 2001, 25, 402-408. [CrossRef]

52. Velikova, V.; Yordanov, I.; Edreva, A. Oxidative stress and some antioxidant systems in acid rain-treated bean plants: Protective role of exogenous polyamines. Plant Sci. 2000, 151, 59-66. [CrossRef]

53. Poór, P.; Patyi, G.; Takács, Z.; Szekeres, A.; Bódi, N.; Bagyánszki, M.; Tari, I. Salicylic acid-induced ROS production by mitochondrial electron transport chain depends on the activity of mitochondrial hexokinases in tomato (Solanum lycopersicum L.). J. Plant Res. 2019, 132, 273-283. [CrossRef] [PubMed]

54. Bradford, M.M. A rapid and sensitive method for the quantitation of microgram quantities of protein utilizing the principle of protein-dye binding. Anal. Biochem. 1976, 72, 248-254. [CrossRef]

55. Brossa, R.; Pintó-Marijuan, M.; Francisco, R.; López-Carbonell, M.; Chaves, M.M.; Alegre, L. Redox proteomics and physiological responses in Cistus albidus shrubs subjected to long-term summer drought followed by recovery. Planta 2015, 241, 803-822. [CrossRef] [PubMed]

56. Yang, P.; Fu, H.; Walker, J.; Papa, C.M.; Smalle, J.; Ju, Y.M.; Vierstra, R.D. Purification of the Arabidopsis $26 \mathrm{~S}$ proteasome biochemical and molecular analyses revealed the presence of multiple isoforms. J. Biol. Chem. 2004, 279, 6401-6413. [CrossRef]

57. Rossano, R.; Larocca, M.; Riccio, P. 2-D zymographic analysis of Broccoli (Brassica oleracea L. var. Italica) florets proteases: Follow up of cysteine protease isotypes in the course of post-harvest senescence. J. Plant Physiol. 2011, 168, 1517-1525. [CrossRef]

58. Ederli, L.; Pasqualini, S.; Batini, P.; Antonielli, M. Photoinhibition and oxidative stress: Effects on xanthophyll cycle, scavenger enzymes and abscisic acid content in tobacco plants. J. Plant Physiol. 1997, 151, 422-428. [CrossRef]

59. Sun, J.; Li, L.; Liu, M.; Wang, M.; Ding, M.; Deng, S.; Chen, S. Hydrogen peroxide and nitric oxide mediate $\mathrm{K}^{+} / \mathrm{Na}^{+}$homeostasis and antioxidant defense in NaCl-stressed callus cells of two contrasting poplars. Plant Cell Tissue Organ Cult. 2010, 103, 205-215. [CrossRef]

60. Dobritzsch, S.; Weyhe, M.; Schubert, R.; Dindas, J.; Hause, G.; Kopka, J.; Hause, B. Dissection of jasmonate functions in tomato stamen development by transcriptome and metabolome analyses. BMC Biol. 2015, 13, 1-18. [CrossRef]

61. Liu, J.J.; Williams, H.; Li, X.R.; Schoettle, A.W.; Sniezko, R.A.; Murray, M.; Zamany, A.; Roke, G.; Chen, H. Profiling methyl jasmonate-responsive transcriptome for understanding induced systemic resistance in whitebark pine (Pinus albicaulis). Plant Mol. Biol. 2017, 95, 359-374. [CrossRef]

62. Qi, X.; Fang, H.; Yu, X.; Xu, D.; Li, L.; Liang, C.; Lu, H.; Li, W.; Chen, Y.; Chen, Z. Transcriptome Analysis of JA Signal Transduction, Transcription Factors, and Monoterpene Biosynthesis Pathway in Response to Methyl Jasmonate Elicitation in Mentha canadensis L. Int. J. Mol. Sci. 2018, 19, 2364. [CrossRef] [PubMed]

63. Luo, J.; Xia, W.; Cao, P.; Xiao, Z.A.; Zhang, Y.; Liu, M.; Zhan, C.; Wang, N. Integrated transcriptome analysis reveals plant hormones jasmonic acid and salicylic acid coordinate growth and defense responses upon fungal infection in poplar. Biomolecules 2019, 9, 12. [CrossRef] [PubMed]

64. Zander, M.; Lewsey, M.G.; Clark, N.M.; Yin, L.; Bartlett, A.; Guzmán, J.P.S.; Hann, E.; Langford, A.E.; Jow, B.; Wise, A.; et al. Integrated multi-omics framework of the plant response to jasmonic acid. Nat. Plants 2020, 6, 290-302. [CrossRef] [PubMed]

65. Pieterse, C.M.; Van Pelt, J.A.; Ton, J.; Parchmann, S.; Mueller, M.J.; Buchala, A.J.; Métraux, J.-P.; Van Loon, L.C. Rhizobacteria-mediated induced systemic resistance (ISR) in Arabidopsis requires sensitivity to jasmonate and ethylene but is not accompanied by an increase in their production. Physiol. Mol. Plant P. 2000, 57, 123-134. [CrossRef]

66. Mehari, Z.H.; Elad, Y.; Rav-David, D.; Graber, E.R.; Harel, Y.M. Induced systemic resistance in tomato (Solanum lycopersicum) against Botrytis cinerea by biochar amendment involves jasmonic acid signaling. Plant Soil 2015, 395, 31-44. [CrossRef] 
67. Pan, G.; Liu, Y.; Ji, L.; Zhang, X.; He, J.; Huang, J.; Qiu, Z.; Liu, D.; Sun, Z.; Xu, T.; et al. Brassinosteroids mediate susceptibility to brown planthopper by integrating with the salicylic acid and jasmonic acid pathways in rice. J. Exp. Bot. 2018, 69, 4433-4442. [CrossRef] [PubMed]

68. Jiang, N.; Fan, X.; Lin, W.; Wang, G.; Cai, K. Transcriptome Analysis Reveals New Insights into the Bacterial Wilt Resistance Mechanism Mediated by Silicon in Tomato. Int. J. Mol. Sci. 2019, 20, 761. [CrossRef]

69. Pozo, M.J.; Van Der Ent, S.; Van Loon, L.C.; Pieterse, C.M. Transcription factor MYC2 is involved in priming for enhanced defense during rhizobacteria-induced systemic resistance in Arabidopsis thaliana. New Phytol. 2008, 180, 511-523. [CrossRef]

70. Jelitto-Van Dooren, E.P.; Vidal, S.; Denecke, J. Anticipating endoplasmic reticulum stress: A novel early response before pathogenesis-related gene induction. Plant Cell 1999, 11, 1935-1943. [CrossRef]

71. Liu, P.P.; von Dahl, C.C.; Klessig, D.F. The extent to which methyl salicylate is required for signaling systemic acquired resistance is dependent on exposure to light after infection. Plant Physiol. 2011, 157, 2216-2226. [CrossRef]

72. Gupta, D.; Tuteja, N. Chaperones and foldases in endoplasmic reticulum stress signaling in plants. Plant Signal. Behav. 2011, 6, 232-236. [CrossRef]

73. Park, C.J.; Seo, Y.S. Heat shock proteins: A review of the molecular chaperones for plant immunity. Plant Pathol. J. 2015, 31, 323. [CrossRef] [PubMed]

74. Seo, H.S.; Song, J.T.; Cheong, J.J.; Lee, Y.H.; Lee, Y.W.; Hwang, I.; Lee, J.S.; Do Choi, Y. Jasmonic acid carboxyl methyltransferase: A key enzyme for jasmonate-regulated plant responses. Proc. Natl. Acad. Sci. USA 2001, 98, 4788-4793. [CrossRef] [PubMed]

75. Leitner, M.; Boland, W.; Mithöfer, A. Direct and indirect defences induced by piercing-sucking and chewing herbivores in Medicago truncatula. New Phytol. 2005, 167, 597-606. [CrossRef] [PubMed]

76. Ruan, J.; Zhou, Y.; Zhou, M.; Yan, J.; Khurshid, M.; Weng, W.; Cheng, J.; Zhang, K. Jasmonic acid signaling pathway in plants. Int. J. Mol. Sci. 2019, 20, 2479. [CrossRef]

77. Denecke, J.; Carlsson, L.E.; Vidal, S.; Höglund, A.S.; Ek, B.; van Zeijl, M.J.; Sinjorgo, K.M.C.; Palva, E.T. The tobacco homolog of mammalian calreticulin is present in protein complexes in vivo. Plant Cell 1995, 7, 391-406.

78. Watanabe, N.; Lam, E. Bax inhibitor-1, a conserved cell death suppressor, is a key molecular switch downstream from a variety of biotic and abiotic stress signals in plants. Int. J. Mol. Sci. 2009, 10, 3149-3167. [CrossRef]

79. Barna, B.; Fodor, J.; Harrach, B.D.; Pogány, M.; Király, Z. The Janus face of reactive oxygen species in resistance and susceptibility of plants to necrotrophic and biotrophic pathogens. Plant Physiol. Biochem. 2012, 59, 37-43. [CrossRef]

80. Kovács, J.; Poór, P.; Szepesi, Á.; Tari, I. Salicylic acid induced cysteine protease activity during programmed cell death in tomato plants. Acta Biol. Hung. 2016, 67, 148-158. [CrossRef]

81. Yue, H.; Nie, S.; Xing, D. Over-expression of Arabidopsis Bax inhibitor-1 delays methyl jasmonate-induced leaf senescence by suppressing the activation of MAP kinase 6. J. Exp. Bot. 2012, 63, 4463-4474. [CrossRef]

82. Ozgur, R.; Uzilday, B.; Sekmen, A.H.; Turkan, I. The effects of induced production of reactive oxygen species in organelles on endoplasmic reticulum stress and on the unfolded protein response in Arabidopsis. Ann. Bot. 2015, 116, 541-553. [CrossRef] [PubMed]

83. Foyer, C.H.; Noctor, G. Redox regulation in photosynthetic organisms: Signaling, acclimation, and practical implications. Antioxid. Redox Signal. 2009, 11, 861-905. [CrossRef] [PubMed]

84. Kocsy, G.; Tari, I.; Vanková, R.; Zechmann, B.; Gulyás, Z.; Poór, P.; Galiba, G. Redox control of plant growth and development. Plant Sci. 2013, 211,77-91. [CrossRef] [PubMed]

85. Van Aken, O.; Van Breusegem, F. Licensed to kill: Mitochondria, chloroplasts, and cell death. Trends Plant Sci. 2015, 20, 754-766. [CrossRef]

86. Mur, L.A.; Prats, E.; Pierre, S.; Hall, M.A.; Hebelstrup, K.H. Integrating nitric oxide into salicylic acid and jasmonic acid/ethylene plant defense pathways. Front. Plant Sci. 2013, 4, 215. [CrossRef]

87. Xia, X.J.; Zhou, Y.H.; Shi, K.; Zhou, J.; Foyer, C.H.; Yu, J.Q. Interplay between reactive oxygen species and hormones in the control of plant development and stress tolerance. J. Exp. Bot. 2015, 66, 2839-2856. [CrossRef] 
88. Hu, X.; Neill, S.; Cai, W.; Tang, Z. Hydrogen peroxide and jasmonic acid mediate oligogalacturonic acid-induced saponin accumulation in suspension-cultured cells of Panax ginseng. Physiol. Plant. 2003, 118, 414-421. [CrossRef]

89. Song, C.J.; Steinebrunner, I.; Wang, X.; Stout, S.C.; Roux, S.J. Extracellular ATP induces the accumulation of superoxide via NADPH oxidases in Arabidopsis. Plant Physiol. 2006, 140, 1222-1232. [CrossRef]

90. Suhita, D.; Raghavendra, A.S.; Kwak, J.M.; Vavasseur, A. Cytoplasmic alkalization precedes reactive oxygen species production during methyl jasmonate-and abscisic acid-induced stomatal closure. Plant Physiol. 2004, 134, 1536-1545. [CrossRef]

91. Ye, W.; Hossain, M.A.; Munemasa, S.; Nakamura, Y.; Mori, I.C.; Murata, Y. Endogenous abscisic acid is involved in methyl jasmonate-induced reactive oxygen species and nitric oxide production but not in cytosolic alkalization in Arabidopsis guard cells. J. Plant Physiol. 2013, 170, 1212-1215. [CrossRef]

92. Abouelsaad, I.; Renault, S. Enhanced oxidative stress in the jasmonic acid-deficient tomato mutant def-1 exposed to $\mathrm{NaCl}$ stress. J. Plant Physiol. 2018, 226, 136-144. [CrossRef] [PubMed]

93. Wendehenne, D.; Durner, J.; Klessig, D.F. Nitric oxide: A new player in plant signalling and defence responses. Curr. Opin. Plant Biol. 2004, 7, 449-455. [CrossRef] [PubMed]

94. Groß, F.; Durner, J.; Gaupels, F. Nitric oxide, antioxidants and prooxidants in plant defence responses. Front. Plant Sci. 2013, 4, 419. [CrossRef] [PubMed]

95. Mur, L.A.; Sivakumaran, A.; Mandon, J.; Cristescu, S.M.; Harren, F.J.; Hebelstrup, K.H. Haemoglobin modulates salicylate and jasmonate/ethylene-mediated resistance mechanisms against pathogens. J. Exp. Bot. 2012, 63, 4375-4387. [CrossRef] [PubMed]

96. Nyström, T. Role of oxidative carbonylation in protein quality control and senescence. EMBO J. 2005, 24, 1311-1317. [CrossRef]

97. Misas-Villamil, J.C.; van der Hoorn, R.A.; Doehlemann, G. Papain-like cysteine proteases as hubs in plant immunity. New Phytol. 2016, 212, 902-907. [CrossRef]

98. Stael, S.; Van Breusegem, F.; Gevaert, K.; Nowack, M.K. Plant proteases and programmed cell death. J. Exp. Bot. 2019, 70, 1991-1995. [CrossRef]

(C) 2020 by the authors. Licensee MDPI, Basel, Switzerland. This article is an open access article distributed under the terms and conditions of the Creative Commons Attribution (CC BY) license (http://creativecommons.org/licenses/by/4.0/). 